\title{
Prevalence of antimicrobial resistant Aeromonas in chicken and fish washings
}

\author{
Pratibha U. Kore, Rahul P. Kolhe*, Padmakar D. Deshpande, Chandrakant D. Bhong, Samir N. \\ Jadhav, Avinash B. Nagargoje, Urmila V. Jagtap, Chandrakant V. Dhandore, Uma M. Tumlam, \\ Prashant D. Pawar and Madhav W. Khasnis
}

Department of Veterinary Public Health and Epidemiology, KNP College of Veterinary Science, Shirwal Dist-Satara412801, Maharashtra, India. (Maharashtra Animal and Fishery Sciences University, Nagpur, Maharashtra, India).

Received 13 March, 2014; Accepted 2 June, 2014

\begin{abstract}
This study was undertaken to assess prevalence of virulent and antibiotic-resistant Aeromonas species in chicken meat and fresh water fish washings procured from local market. Isolation was done on three selective agar viz. Aeromonas isolation media, ampicillin dextrin agar and Aeromonas starch DNA agar. Presumptive colonies were directly screened by multiplex polymerase chain reaction (PCR) targeting genus specific 16S rRNA gene, aerolysin (aerA) of Aeromonas hydrophila and hemolysin (asa1) gene of Aeromonas sobria. Of the 200 samples (100 each of chicken and fish washings), 21 isolates were confirmed as Aeromonas species. We could not detect aer $A$, however, asa1 of $A$. sobria was detected in six (28.57\%) fish isolates. Aeromonas isolates exhibited $100 \%$ resistant to amoxicillin, ampicillin and 95.23\% to carbenicillin. Moderate sensitivity was observed to kanamycin $(90.47 \%)$ and neomycin (71.42\%). Isolates were $100 \%$ sensitive to gentamicin and ciprofloxacin. Maximum sensitivity was recorded with chloramphenicol, tobramycin (95.23\% each) and amikacin $(80.95 \%)$. PCR characterization revealed presence of class 1 integron and Tet $(C)$ genes in six and 10 isolates, respectively. PSE-1 $\beta$ lactamase was not detected in any of the isolates. This study demonstrate the incidence of antimicrobial resistant Aeromonas in chicken and fish environment, which may be a potential source of spread of this enteropathogen in food chain.
\end{abstract}

Key words: Aeromonads, antimicrobial resistance, chicken, fish.

\section{INTRODUCTION}

Aeromonas species are ubiquitous Gram negative bacilli, nowadays classified within the new Aeromonadaceae family (Martin-Carnahan and Joseph, 2005). They are widely distributed in aquatic environments and are isolated from a wide range of food of animal and plant origin. Exotoxins are major virulence factors of aeromonads that include a cytotoxic heat-labile enterotoxin (Act), also known as aerolysin/hemolysin; a cytotonic heat-labile enterotoxin (Alt), known as lipase, extracellular lipase, or phospholipase and a cytotonic

${ }^{*}$ Corresponding author. E-mail: dr_kolherahul@rediffmail.com.

Author(s) agree that this article remain permanently open access under the terms of the Creative Commons Attribution License 4.0 International License 
heat-stable enterotoxin (Ast) (Kingombe et al., 2010). Other than gastroenteritis, Aeromonas are responsible for meningitis, cellulites, otitis, endocarditis, osteomyelitis, peritonitis, bacteremia and septicemia (Albert et al., 2000). Motile aeromonads due to their ubiquitous distribution are considered as bacterial indicators of fresh water environment, especially for harboring resistance genes (Schmidt et al., 2001). In India, incidence of Aeromonas species is reported from various foods of animal origin viz. fish, seafood, raw and cooked meat, poultry, vegetables, milk and milk products (Khurana and Kumar, 1997; Agarwal et al., 2000), however, reports on detection of virulence and drug resistance genes are limited. Antimicrobial resistance among enteric pathogens is a serious problem in developing countries where there is a high frequency of gastroenteric illnesses and many antibiotics fall routinely into inadequate use. Acquisition of new genetic material by susceptible bacteria from resistant strains often facilitates the incorporation of the multiple resistance genes into the host's genome or plasmids (Tenover, 2006). The consequences of horizontal gene transfer are even more alarming. This mechanism can often promote the simultaneous spread of resistance to several unrelated classes of antibiotics, particularly if the genes for such resistance are colocated on the transmissible genetic element. Antimicrobial-resistant populations are present everywhere in all bacterial communities. Their expansion follows complex pathways through environmental systems, people, animals, food and water. Therefore, surveillance of antimicrobial resistance in commensal, zoonotic and pathogenic bacteria from humans, animals and food is crucial while formulating food safety measures (Acar and Moulin, 2013). Considering the high frequency of Aeromonas in poultry feces, poultry carcasses can be considered as a risk group for Aeromonas infections and dissemination (Jindal et al., 1993). $\beta$-Lactam antibiotics are commonly used in the treatment of bacterial infections but they are hydrolysed by $\beta$-lactamase enzymes produced by resistant bacteria ( $\mathrm{Li}$ et al., 2009). Also, class I integrons are usually reported to contain antibiotic-resistant gene cassettes and related with other mobile elements such as plasmids, which could contribute to the dissemination of resistance genes (Agers $\varnothing$ and Sandvang, 2005). Antimicrobials are also used in the aquaculture environment which may create selective pressure on bacterial environment. In view of these facts, the aim of the study was to estimate prevalence of Aeromonas hydrophila and Aeromonas sobria in chicken and fish washings and to find their antimicrobial resistance pattern.

\section{MATERIALS AND METHODS}

\section{Sample collection}

Chicken meat (100) and fish washings (100) were collected aseptically during January to October, 2013 from the local market in
Shirwal. Approximately $50 \mathrm{~g}$ chicken and $10 \mathrm{ml}$ fish washing water were collected in pre-sterilized specimen tubes and transported on ice to the laboratory for bacterial isolation. Samples collected were further processed on the day of collection for isolation of Aeromonas species.

\section{Isolation and identification of Aeromonas species}

For isolation, enrichment was done in alkaline peptone water (APW). Approximately, $10 \mathrm{~g}$ of chicken meat sample homogenized with $90 \mathrm{ml}$ sterile normal saline solution (NSS), and $1 \mathrm{ml}$ homogenate was further transferred to $9 \mathrm{ml}$ APW. From fish washings, $1 \mathrm{ml}$ of sample was inoculated with $9 \mathrm{ml}$ of APW according to the methods described by Agarwal et al. (2003) and HiMedia (2009). After enrichment at $37^{\circ} \mathrm{C}$ for $18 \mathrm{~h}$, selective plating was done on Aeromonas isolation media, ampicillin dextrin agar (ADA) and Aeromonas Starch DNA agar. After inoculation agar plates were incubated at $37^{\circ} \mathrm{C}$ for $24 \mathrm{~h}$. Presumptive identification of Aeromonas species was based on colony characteristics, morphology and Gram's staining. Presumptive colonies were further subcultured on ADA and subjected to molecular studies. Aeromonas colonies on ADA are yellow with dark orange centre, on Aeromonas isolation media are dark green colored clear to slightly opalescent and on Aeromonas Starch DNA agar are creamy. Candidate colonies were further kept at $4^{\circ} \mathrm{C}$ in brain heart infusion $(\mathrm{BHI})$ broth until use. All the bacteriological media were procured from HiMedia Laboratories Private Limited, Mumbai, India.

\section{Antimicrobial susceptibility testing}

Antibiotic sensitivity was determined by single disc diffusion method of Bauer et al. (1966) using Mueller Hinton agar (MHA). Bacteria were cultivated in $\mathrm{BHI}$ broth and incubated for $12 \mathrm{~h}$ at $37^{\circ} \mathrm{C}$. Further, the bacterial suspension were seeded onto MHA plates. Antimicrobial profiles of Aeromonas isolates were studied against 12 different antimicrobials viz. amikacin (AK, $30 \mathrm{mcg} / \mathrm{disc}$ ), amoxicillin (AMX, $30 \mathrm{mcg} / \mathrm{disc}$ ), ampicillin (AMP,10 mcg/disc), carbenicillin (CB, $100 \mathrm{mcg} / \mathrm{disc}$ ), cephalothin (CEP, $30 \mathrm{mcg} / \mathrm{disc}$ ), chloramphenicol (C, $30 \mathrm{mcg} / \mathrm{disc})$, ciprofloxacin (CIP, $5 \mathrm{mcg} / \mathrm{disc})$ gentamicin (GEN, $30 \mathrm{mcg} / \mathrm{disc})$, kanamycin (K, $30 \mathrm{mcg} / \mathrm{disc}$ ), neomycin ( $\mathrm{N}, 30 \mathrm{mcg} / \mathrm{disc}$ ), tobramycin (TOB, $10 \mathrm{mcg} / \mathrm{disc}$ ), tetracycline (TE, $30 \mathrm{mcg} / \mathrm{disc})$. Zones of inhibition were read after incubation at $37^{\circ} \mathrm{C}$ for $24 \mathrm{~h}$ in accordance with Performance Standards for Antimicrobial Disk Susceptibility Tests, CLSI as mentioned by the manufacturer of antimicrobial discs (HiMedia Laboratories, Mumbai).

\section{Molecular detection}

Genus and species specific multiplex PCR assay was performed for detection of Aeromonas species targeting conserved and virulence genes according to the methods described by Wang et al. (2003) with suitable modifications. Briefly, presumptive colonies were further subcultured on ADA. All PCR reactions, both for virulence associated gene and antimicrobial genes were performed by colony PCR in $25 \mu \mathrm{l}$ containing $12.5 \mu \mathrm{l} \mathrm{PCR}$ master mix (HiMedia), $1 \mu \mathrm{l}(10$ picomoles) forward $(F)$ and reverse $(R)$ primers, $7.5 \mu$ l nuclease free water and a pure single colony as a DNA template. Bacterial colonies were picked up with sterilized tooth pick and directly transferred to PCR tubes. The program was run on a Verity 96 well thermal cycler PCR system (Applied Biosystems). The PCR products were cooled at $4^{\circ} \mathrm{C}$ and resolved by submarine gel electrophoresis on $1.5 \%$ agarose gel. Each run contained a $100 \mathrm{bp}$ DNA molecular weight marker (GeneRuler, Fermentas). The gels were stained with ethidium bromide $(0.5 \mu \mathrm{g} / \mathrm{ml})$, observed under UV 
Table 1. Oligonucleotide sequences used for detection of different genes in Aeromonas species.

\begin{tabular}{|c|c|c|c|}
\hline Target gene & Primer sequence & $\begin{array}{l}\text { Amplicon size } \\
\text { (bp) }\end{array}$ & Reference \\
\hline 16S rRNA & $\begin{array}{l}\text { F- GGGAGTGCCTTCGGGAATCAGA } \\
\text { R- TCACCGCAACATTCTGATTTG }\end{array}$ & 356 & Wang et al. (2003) \\
\hline asa 1 of $A$. sobria & $\begin{array}{l}\text { F- TAAAGGGAAATAATGACGGCG } \\
\text { R- GGCTGTAGGTATCGGTTTTCG }\end{array}$ & 249 & Wang et al. (2003) \\
\hline aerA of $A$. hydrophila & $\begin{array}{l}\text { F- CAAGAACAAGTTCAAGTGGCCA } \\
\text { R-ACGAAGGTGTGGTTCCAGT }\end{array}$ & 309 & Wang et al. (2003) \\
\hline$P S E \beta$-lactamase & $\begin{array}{l}\text { F- ACCGTA TTGAGCCTG ATT TA } \\
\text { R- ATT GAAGCC TGT GTT TGAGC }\end{array}$ & 321 & Bert et al. (2002) \\
\hline Class 1 integron & $\begin{array}{l}\text { F- GGC ATC CAA GCA GCA AG } \\
\text { R- GGC ATC CAA GCA GCA AG }\end{array}$ & 410 & $\begin{array}{l}\text { Igbinosa and Okoh, } \\
\text { (2012) }\end{array}$ \\
\hline Tet C & $\begin{array}{l}\text { F- GGT TGA AGG CTC TCA AGG GC } \\
\text { R- CCT CTT GCG GGA TAT CGT CC }\end{array}$ & 505 & $\begin{array}{l}\text { Agerso and } \\
\text { Sandvang, (2005) }\end{array}$ \\
\hline
\end{tabular}

Table 2. PCR conditions used for detection of antimicrobial resistance genes in Aeromonas species.

\begin{tabular}{llllll}
\hline Target gene & $\begin{array}{l}\text { Initial } \\
\text { denaturation }\end{array}$ & Denaturation & Annealing & Extension & Final extension \\
\hline$P S E \beta$-lactamase & $96^{\circ} \mathrm{C} / 5 \mathrm{~min}$ & $96^{\circ} \mathrm{C} / 30 \mathrm{~s}$ & $55^{\circ} \mathrm{C} / 30 \mathrm{~s}$ & $72^{\circ} \mathrm{C} / 60 \mathrm{~s}$ & $72^{\circ} \mathrm{C} / 5 \mathrm{~min}$ \\
Class 1 integron & $94^{\circ} \mathrm{C} / 5 \mathrm{~min}$ & $95^{\circ} \mathrm{C} / 45 \mathrm{~s}$ & $56^{\circ} \mathrm{C} / 60 \mathrm{~s}$ & $72^{\circ} \mathrm{C} / 90 \mathrm{~s}$ & $72^{\circ} \mathrm{C} / 10 \mathrm{~min}$ \\
Tet C & $94^{\circ} \mathrm{C} / 5 \mathrm{~min}$ & $94^{\circ} \mathrm{C} / 60 \mathrm{~s}$ & $65^{\circ} \mathrm{C} / 60 \mathrm{~s}$ & $72^{\circ} \mathrm{C} / 60 \mathrm{~s}$ & $72^{\circ} \mathrm{C} / 10 \mathrm{~min}$ \\
\hline
\end{tabular}

Repeated 30 cycles for each gene.

light at a $\lambda 420 \mathrm{~nm}$ and images were captures through gel documentation system (G Box, Syngene UK).

For detection of $16 S$ rRNA gene, and two virulence associate species specific genes viz. aerolysin gene (aerA) of $A$. hydrophila and hemolysin gene (asa1) of $A$. sobria, a multiplex PCR assay was carried out with pre-denaturation at $95^{\circ} \mathrm{C}$ for $5 \mathrm{~min}$, followed by 35 cycles of denaturation at $95^{\circ} \mathrm{C}$ for $30 \mathrm{~s}$, annealing at $59^{\circ} \mathrm{C}$ for $30 \mathrm{~s}$, extension at $72^{\circ} \mathrm{C}$ for $30 \mathrm{~s}$, and final extension at $72^{\circ} \mathrm{C}$ for $7 \mathrm{~min}$. Particulars of oligonucleotide sequences and PCR conditions used for detection of antimicrobial resistance genes are shown in Tables 1 and 2 .

\section{RESULTS}

Aeromonads were isolated from 21 (10.5\%) out of 200 samples (100 each of chicken and fish washings). Prevalence of Aeromonas was recorded higher (15\%) in fish washings as compared to chicken (6\%). We used three selective media viz. ADA, Aeromonas isolation media, and Aeromonas Starch DNA agar for isolation of mesophillic aeromonads. Findings revealed that ADA is the best suitable bacteriological media for recovery of Aeromonas species from food samples. The recorded prevalence is the actual prevalence based on molecular confirmation of the isolates targeting 16S rRNA gene. Screening of the Aeromonas isolates for aerolysin $A$ (aerA) of $A$. hydrophila and asa1 hemolysin gene of $A$. sobria revealed presence of asa1 in six (28.57\%) isolates. None of the isolates were positive for aerolysin A (Figure 1). All the isolates showing positivity for asa1 were from fish source. Thus only $A$. sobria could be detected and we could not isolate virulent $A$. hydrophila.

All the Aeromonas isolates irrespective of the source exhibited moreover similar profile in terms of sensitivity and resistance to the antimicrobials (Table 3 ). They were $100 \%$ resistant to amoxicillin, ampicillin and $95.23 \%$ to carbenicillin. Moderate sensitivity was observed to kanamycin $(90.47 \%)$ and neomycin $(71.42 \%)$. The percent sensitivity was observed against gentamicin and ciprofloxacin. Maximum sensitivity was recorded with chloramphenicol (95.23\%), tobramycin $(95.23 \%)$ and amikacin (80.95\%).

Antibiotic resistance profiles of all 21 Aeromonas isolates was assessed genotypically for association of PSE $\beta$-lactamase, class 1 integron and Tet (C) tetracycline genes. Genomic resistant to PSE $\beta$ lactamase was not detected in any of the isolates, however, distribution of class 1 integron and Tet (C) was observed. Class 1 integron cassette was detected in six $(28.57 \%)$ aeromonads and all were from fish washings (Figure 2). Ten isolates $(47.62 \%)$ showed positive amplification of Tet (C), three from chicken and seven were from fish washings (Figure 3). Combination of class 1 integron and Tet (C) was also recorded in three $(14.28 \%)$ aeromonads in the present study. 


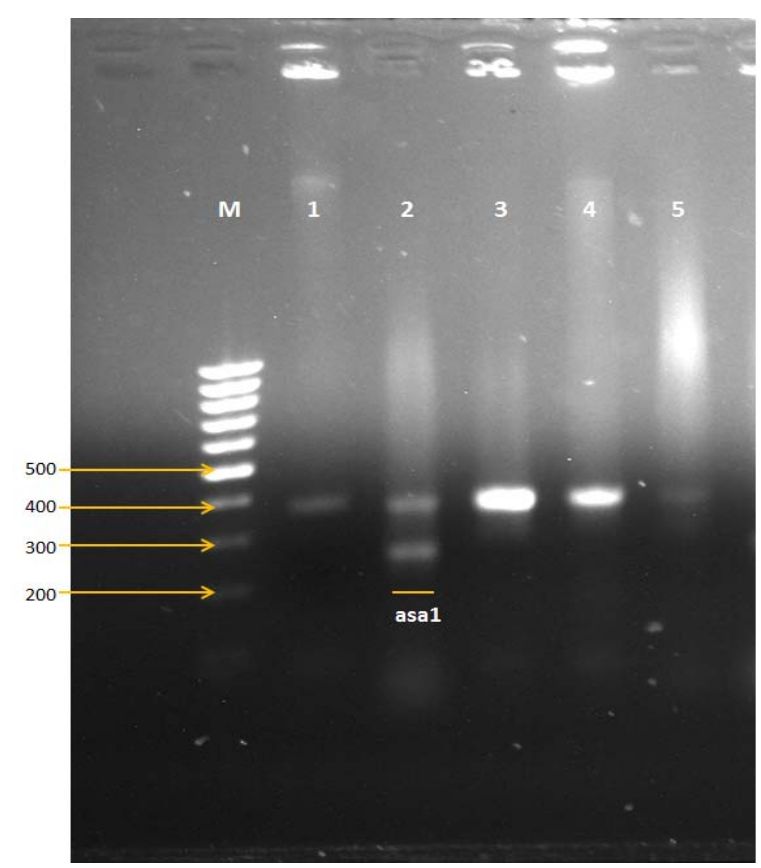

Figure 1. Detection of Aeromonas genus specific $16 S$ rRNA and asa1 genes. M- 100 bp DNA ladder, Lanes: 1-4 (16S rRNA gene-356 bp); Lane: 2-16S rRNA and asa1 gene (249 bp).

Table 3. Antimicrobial sensitivity test of Aeromonas isolates

\begin{tabular}{lcccccc}
\hline \multirow{2}{*}{ Antibiotic } & \multicolumn{2}{c}{ Resistant } & \multicolumn{2}{c}{ Moderate sensitive } & \multicolumn{2}{c}{ Sensitive } \\
\cline { 2 - 7 } & (No.) & (percent) & (No.) & (percent) & (No.) & (percent) \\
\hline Amikacin & 4 & 19.04 & 0 & 0.00 & 17 & 80.95 \\
Amoxicillin & 21 & 100.00 & 0 & 0.00 & 0 & 0.00 \\
Ampicillin & 21 & 100.00 & 0 & 0.00 & 0 & 0.00 \\
Carbenicillin & 20 & 95.23 & 1 & 4.76 & 0 & 0.00 \\
Cephalothin & 14 & 66.66 & 2 & 9.52 & 5 & 23.80 \\
Chloramphenicol & 0 & 0.00 & 1 & 4.76 & 20 & 95.23 \\
Ciprofloxacin & 0 & 0.00 & 0 & 0 & 21 & 100.00 \\
Gentamicin & 0 & 0.00 & 0 & 0 & 21 & 100 \\
Kanamycin & 0 & 0.00 & 19 & 90.47 & 2 & 9.52 \\
Neomycin & 0 & 0.00 & 15 & 71.42 & 6 & 28.57 \\
Tetracycline & 0 & 0.00 & 6 & 28.57 & 15 & 71.42 \\
Tobramycin & 0 & 0.00 & 1 & 4.76 & 20 & 95.23 \\
\hline
\end{tabular}

\section{DISCUSSION}

Observed prevalence in the present study is comparable with previous reports from India especially from foods of animal origin (Yadav and Verma, 1998; Agarwal et al., 2000; Kumar et al., 2000; Rathore et al., 2005; Shinde et al., 2005; Smita et al., 2011). Aforementioned researchers observed the incidence of aeromonads with varying percentage in the range of 8 to $55 \%$. Agarwal et al. (2000) isolated aeromonads from fish (22\%) and goat meat (8.9\%). Kumar et al. (2000) also reported close prevalence of Aeromonas, $16.7 \%$ in poultry meat, $12 \%$ in chevon and $7.7 \%$ in buffalo meat. Rathore et al. (2005) recorded higher prevalence of aeromonads in water and fish with $A$. hydrophila as a predominant species $(43 \%)$ followed by $A$. sobria and $A$. veronii (13\%, each). Shinde et al. (2005) observed moderate incidence of $24 \%$ in poultry meat, however, very high prevalence of $55 \%$ was 


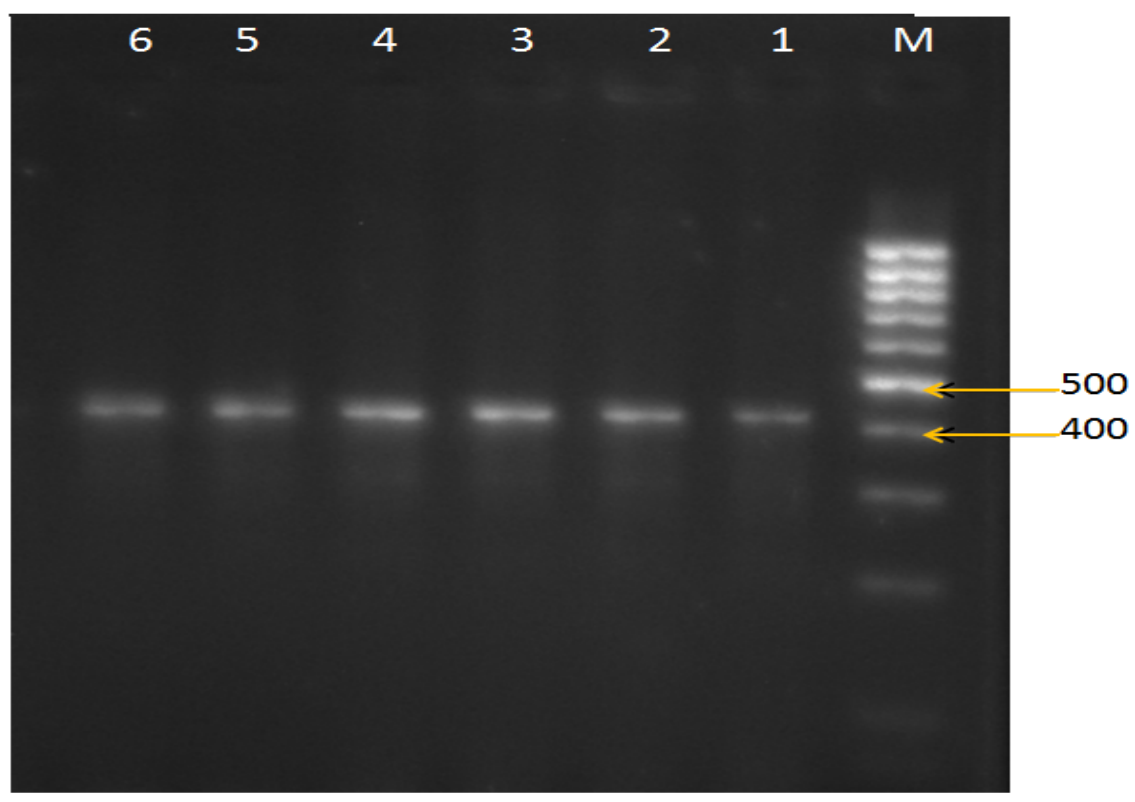

Figure 2. Detection of Class 1 integron gene in Aeromonas isolates (410 bp). M- 100 bp DNA ladder, Lanes : 1 - 6 (class 1 integron genes).

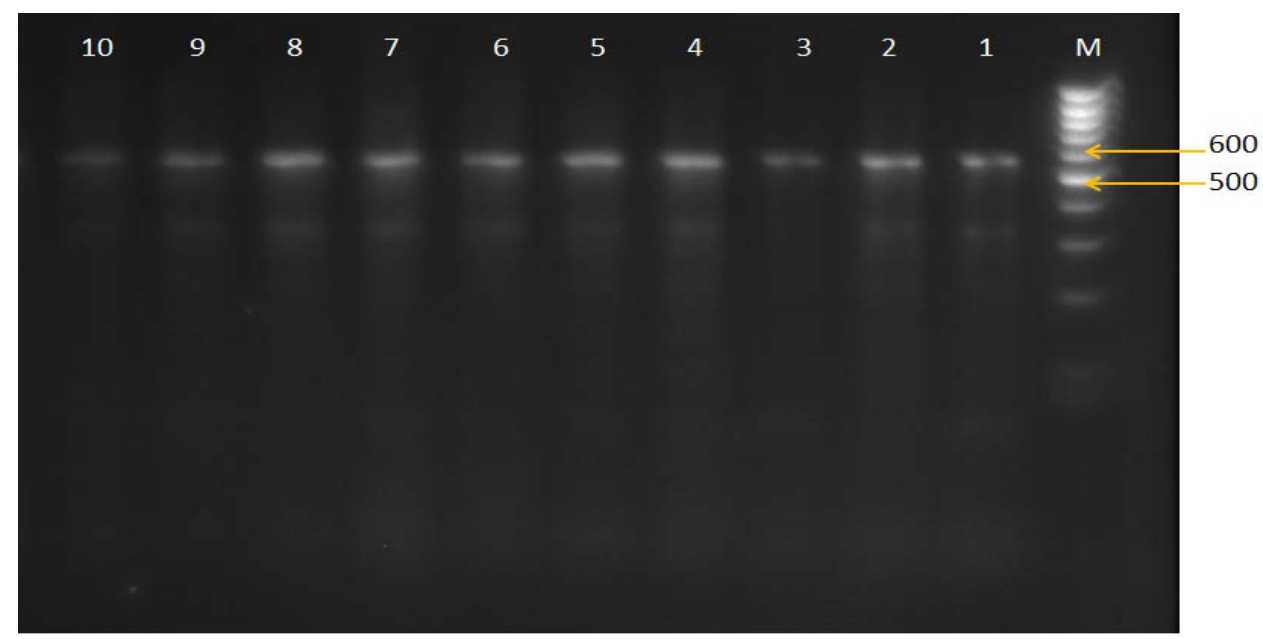

Figure 3. Detection of tetracycline Tet (C) gene in Aeromonas isolates (505 bp). M- 100 bp DNA ladder, Lanes: 1- 10 (Tet C- gene).

found in the studies of Smita et al. (2011). Variation in geographical distribution to certain extent has also been documented by Sinha et al. (2004). Literatures from other part of the world revealed widespread distribution of Aeromonas species in meat, fish and fresh water environment (Hanninen and Sitonen, 1995; Akan et al., 1998; Neyts et al., 2000; Villari et al., 2000; Dallal et al., 2012). Presence of Aeromonas species in foods of animal origin, water environment and retail foods as evident from the available literatures may indicate that these products can act as possible source of vehicles for dissemination of food-borne Aeromonas gastroenteritis (Neyts et al., 2000; Bhowmik et al., 2009).

Present findings emphasize the need of more intensive study on distribution of aeromonads in soil, water environment and foods of animal origin considering its public health implications. Hygiene at retail chicken shop where samples were collected, was heavily compromised and water use for carcass washing may be important critical point in carcass contamination from wide number of gastrointestinal food-borne zoonotic pathogens. It was observed that water kept in bucket for washing either fish 
or chicken carcass was not subject to frequent change and used for dipping of number subjects.

High level of resistance encountered against amoxicillin is alarming since this antibiotic is frequently used in aquaculture operations in order to treat fish diseases. The present findings are in tune with John and Hatha (2012) wherein amoxicillin, carbenicillin and cephalothin resistant strains were detected from fresh water fish. Antimicrobial resistance in fish could be attributed to the practice of using antimicrobials in hatcheries and aquaculture for control of bacterial diseases in fish. Our findings are not in agreement with the findings of Dallal et al. (2012) wherein, number of the aeromonads isolated from ground meat and chicken exhibited resistance to cephalothin (82.5\%), tetracycline (69\%), kanamycin $(25 \%)$ and neomycin (4\%). Results of the present study are also in tune with the findings of Sharma et al. (2010) who isolated ciprofloxacin and amikacin sensitive Aeromonas strains from various foods of animal origin including fish. Ghenghesh et al. (2013) recorded significantly higher tetracycline resistance in aeromonads from chicken carcass $(33 \%)$ in contrast with the present study. Tetracyclines are common additives in poultry feed which can contribute to acquired resistance in poultry. We could not record resistance to tetracycline phenotypically but could detect presence of Tet (C) genes Aeromonas isolates. As tetracycline has been a widely used antibiotic because of its low toxicity and broad spectrum activity, tetracycline resistance gene was studied. The broad ecological presence of $\operatorname{tet}(\mathrm{C})$ is not surprising, since it has been widely distributed in different bacterial genera (Aminov et al., 2002).

Since, laboratory procedures for isolation and identification of aeromonads are laborious and time consuming, several virulence associated genes have been targeted for detection of potentially pathogenic aeromonads by PCR including hemolysin, cytolysin, aerolysin genes (Wang et al., 2003; Aslani and Hamzeh, 2004; Balakrishna et al., 2010). Earliest report on development of PCR assay to detect aerolysin gene in $A$. hydrophila is from Pollard et al. (1990) with a detection limit of $1 \mathrm{ng}$ of total nucleic acid. Recently, multiplex PCR method for detection of three Aeromonas enterotoxin genes viz. cytotoxic (act), heat labile (alt), and heat stable (ast) was developed by Kingombe et al. (2010). Their finding revealed act and alt as most dominant genes in food-borne Aeromonas isolates. A PCR reaction was also standardized by Porteen et al. (2007) for detection of Aeromonas species from chicken and fish samples using primers against $16 S$ rRNA and aerolysin gene.

Based on the results of PCR, only $A$. sobria could be detected and we could not isolate $A$. hydrophila. However, as the strains were confirmed as aeromonads targeting 16S rRNA genes, further studies on isolation and characterization of Aeromonas species from wide range of food and environmental sources is needed. Wang et al. (2003) detected aerolysin gene in $55 \%$ and asa1 gene in $12.05 \%$ of the aeromonads isolated from sporadic cases of human diarrhoea. The hly and aerA positive genotype was most common genotype found in the study of Aslani and Hamzeh (2004) conducted on Aeromonas species isolated from diarrheal human cases and Gonzalez-Rodriguez et al. (2002) in raw and coldsmoked freshwater fish. Nagar et al. (2011) also revealed prevalence of hly and aerA positive aeromonads isolated from chicken, fish and ready to eat sprouts from Mumbai.

Genotypically, resistance to PSE1 $\beta$-lactamase could not be detected, however, distribution of class 1 integron and Tet $(C)$ was observed. Findings of the present study are in corroboration with Schmidt et al. (2001) and Igbinosa and Okoh (2012) in terms of detection of class 1 integron but contrast for Tet (C). Both authors could not detect Tet (C) in Aeromonas species; however class 1 integron gene cassette was detected. Agerso and Sandvang (2005) investigated the role of environmental bacteria as a reservoir for spread of antimicrobial resistance between the animals and human population. Their study revealed that soil bacteria may play important role in horizontal transfer of plasmid mediated resistance encoded by class 1 integron genes cassette and tet genes. Diversity in the gene cassette of class 1 integron was also observed in another study, wherein $13.9 \%$ Aeromonas isolates from human clinical cases were positive for class 1integron (Lee et al., 2008). The detection of class 1 integron indicates the potential spread of antimicrobial resistance genes within the Enterobacteriaceae family in the simulated environment. Presence of $\beta$-lactamase genes in Aeromonas has been reported by Igbinosa and Okoh (2012) which is an alarming public health concern.

Member of the genus Aeromonas readily develop single or multiple antimicrobial resistance phenotypes, and R-plasmids are commonly found, thus they are well suited for monitoring the incidence of antibiotic resistance, as well as for investigating the conjugative spread of resistance genes (Schmidt et al., 2001). Since antibiotic resistance exists in bacteria in different and potentially linked reservoirs, an integrated laboratorybased surveillance programme for monitoring resistance in all relevant reservoirs is needed.

\section{Conflict of Interests}

The author(s) have not declared any conflict of interests.

\section{ACKNOWLEDGEMENTS}

We gratefully acknowledge Associate Dean of the institute and In-Charge of CIF for providing financial and technical support.

\section{REFERENCES}

Acar JF, Moulin G (2013). Integrating animal health surveillance and 
food safety: the issue of antimicrobial resistance. Rev. Sci. Tech. Off. Int. Epiz. 32:383-392.

Agarwal RK, Bhilegaonkar KN, Singh DK, Kumar A, Rathore RS (2003). Laboratory manual for the isolation and identification of foodborne pathogen 1st Edn, Indian Veterinary Research Institute Izatnagar. 3031.

Agarwal RK, Kapoor KN, Kumar A, Bhilegaonkar KN (2000). Aeromonads in foods of animal origin. Indian J. Anim. Sci. 70:942943.

Agerso Y, Sandvand D (2005). Class 1 integrons and tetracycline resistance genes in Alcaligenes, Arthrobacter and Pseudomonas species isolated from piglets and manured soil. Appl. Environ. Microbiol. 71:7941-7947.

Akan M, Eyigor A, Diker KS (1998). Motile aeromonads in the feces and carcasses of broiler chickens in Turkey. J. Food Prot. 61: 113-115.

Albert MJ, Ansaruzzaman M, Talukder KA, Chopra AK, Kuhn I, Rahman M, Faruque ASG, Islam MS, Sack RB, Roland Mollby (2000). Prevalence of enterotoxin genes in Aeromonas spp. isolated from children with diarrhea, healthy controls, and the environment. J. Clin. Microbiol. 38:3785-3790.

Aminov RI, Chee-Sanford JC, Garrigues N, Teferedegne B, Krapac IJ, White BA, Mackie RI (2002). Development, validation, and application PCR primers for detection of tetracycline Efflux Genes of Gram-Negative Bacteria. Appl. Environ. Microbiol. 68:1786-1793.

Aslani MM, Hamzeh HS (2004). Characterization and distribution of virulence factors in Aeromonas hydrophila strains isolated from fecal samples of diarrheal and asymptomatic healthy persons, in Ilam, Iran. Iran. Biomed. J. 8: 199-203.

Balakrishna K, Murali HS, Batra HV (2010). Detection of toxigenic strains of Aeromonas species in foods by a multiplex PCR assay. Indian J. Microbiol. 50:139-144.

Bauer AW, Kirby WMM, Sherries JC, Turk M (1966). Antibiotic susceptibility testing. Am. J. Pathol. 45:493-496.

Bert F, Branger C, Lambert-Zechovsky N (2002). Identification of PSE and OXA $\beta$-lactamase genes in Pseudomonas aeruginosa using PCR-restriction fragment length polymorphism. J. Antimicrob. Chemother. 50:11-18.

Bhowmik P, Bag PK, Hajra TK, Sarkar RP, Ramamurthy T (2009). Pathogenic potential of Aeromonas hydrophila isolated from surface waters in Kolkata, India. J. Med. Microbiol. 58:1549-1558.

Dallal SM, Yazdi KS, Avadisians S (2012). Study of prevalence and antibiotic resistance in Aeromonas species isolated from minced meat and chicken samples in Iran. Afr. J. Microbiol. Res. 6: 460-464.

Ghenghesh KS, El-Mohammady H, Levin SY, Zorgani A, Tawil K (2013). Antimicrobial resistance profile of Aeromonas species isolated from Libya. Libyan J. Med. 8:213-220.

Gonzalez-Rodrıguez MN, Santos JA, Otero A, Garcıa-Lopez ML (2002) PCR detection of potentially pathogenic aeromonads in raw and coldsmoked freshwater fish. J. Appl. Microbiol. 93:675-680.

Hanninen ML, Siitonen A (1995). Distribution of Aeromonas phenospecies and genospecies among strains isolated from water, foods or from human clinical samples. Epidemiol. Infect. 115:39-50.

HiMedia Laboratories (2009). The HiMedia Manual: A manual of microbiology laboratory practice, HiMedia Laboratories Pvt. Ltd. Mumbai.

Igbinosa IH, Okoh Al (2012). Antibiotic susceptibility profile of Aeromonas species isolated from wastewater treatment plant. Sci. World J. 764563:1-6.

Jindal N, Garg SR, Kumar A (1993). Comparision of Aeromonas species isolated from human, livestock and poultry feces. Isr. J. Vet. Med. 48:80-82.

John N, Hatha AAM (2012). Prevalence, distribution and drug resistance of motile aeromonads in freshwater ornamental fishes. Indian J. Fish.59:161-164.
Khurana R, Kumar A (1997). Prevalence of motile Aeromonads in foods of animal origin. J. Food Sci. Technol. 34:228-229.

Kingombe Cl, D'Aoust JY, Huys G, Hofmann L, Rao M, Kwan J (2010). Multiplex PCR method for detection of three Aeromonas enterotoxin genes. Appl. Environ. Microbiol. 76:425-433.

Kumar A, Bacchil VN, Bhilegaonkar KN, Agarwal RK (2000). Occurrence of entoroxigenic Aeromonas species in foods. J. Commun. Dis. 32:169-174.

Li D, Yang M, Hu J (2009). Antibiotic resistance profile in environmental bacteria isolated from penicillin production waste water treatment plant and the receiving river. Environ. Microbiol. 11:1506-1517.

Martin- Carnahan A, Joseph SW (2005). Genus Aeromonas In Bergy's Manual of Syatematic Bactiriology, Second Edition, vol 2 (The Proteobacteria), part B (The Gammaproteobacteria), Edn, DJ Brenner et al., Springer, New York. pp. 558.

Nagar V, Shashidhar R, Bandekar JR (2011). Prevalence, characterization, and antimicrobial resistance of Aeromonas strains from various retail food products in Mumbai, India. J. Food Sci. 2011 76: M486-492.

Neyts K, Huys G, Uyttendaele M, Swings J, Debevere J (2000). Incidence and identification of mesophillic Aeromonas species from retail foods. Lett. Appl. Microbiol. 31: 359-363.

Pollard DR, Johnson WM, Lior H, Tyler SD, Rozee KR (1990). Detection of the aerolysin gene in Aeromonas hydrophila by the Polymerase Chain Reaction. J. Clin. Microbiol. 28:2477-2481.

Porteen K, Agarwal RK, Bhilegaonkar KN (2007). Detection of Aeromonas species from chicken and fish samples by Polymerase Chain Reaction. Am. J. Food Technol. 2:30-37.

Rathore G, Swaminathan, Abidi R, Mahanta PC, Kappor D (2005). Isolation and characterization of motile aeromonads from aquatic environment. Indian J. Fish. 52:241-248.

Schmidt AS, Morten SB, Dalsgaard I, Larsen JL (2001). Incidence, distribution, and spread of tetracycline resistance determinants and integron-associated antibiotic resistance genes among motile aeromonads from a fish farming environment. Appl. Environ. Microbiol. 67: 5675-5682.

Sharma I., Kumar A, Pramanik AK (2010). Antibiotic sensitivity test of aeromonads isolated from foods of animal origin including fish. Assam Univ. J. Sci. Technol. $5:$ 43-47.

Shinde SV, Zade NN, Kolhe RP, Karpe AG (2005). Prevalence of multiple drug resistance Aeromonas species from chicken. J Bombay Vet. Coll. 13:36-39.

Sinha S, Shimada T, Ramamurthy T, Bhattacharya SK, Yamasaki S, Takeda Y, Nair GB (2004). Prevalence, serotype distribution, antibiotic susceptibility and genetic profiles of mesophilic Aeromonas species isolated from hospitalized diarrhoeal cases in Kolkata, India J. Med. Microbiol. 53: 527-534.

Smita, Bhong CD, Brahmbhatt MN (2010). Selective culture media for the recovery of Aeromonas species from poultry meat. Ind. J. Vet. Res. 20:66-68.

Tenover FC (2006). Mechanism of antimicrobial resistance in bacteria. Am. J. Med. 119: S3-S10.

Villari P, Crispino M, Montuori P, Stanzione S (2000). Prevalence and molecular characterization of Aeromonas species in ready-to-eat foods in Italy. J. Food Prot. 63:1754-1757.

Wang G, Clifford G. Clark CG, Liu C, Pucknell C, Munro CK, Kruk Tamara MAC, Caldeira R, Woodward DL, Rodgers FG (2003). Detection and characterization of the hemolysin genes in Aeromonas hydrophila and Aeromonas sobria by Multiplex PCR. J. Clin. Microbiol. 41:1048-1054.

Yadav AS, Verma SS (1998). Occurrence of enterotoxigenic Aeromonas in poultry eggs and meat. J. Food Sci. Technol. 35:169170. 